\title{
Seeking asylum in Scandinavia: a comparative analysis of recent restrictive policy responses towards unaccompanied afghan minors in Denmark, Sweden and Norway
}

\author{
Marianne Garvik ${ }^{1 *}$ id and Marko Valenta ${ }^{2}$
}

\author{
* Correspondence: marianne. \\ garvik@ntnu.no \\ ${ }^{1}$ Norwegian University of Science \\ and Technology (NTNU), \\ Trondheim, Norway \\ Full list of author information is \\ available at the end of the article
}

\begin{abstract}
This article investigates recently imposed restrictions in the asylum regimes in Denmark, Sweden and Norway. The purpose of the paper is twofold. First, we aim to identify general changes in asylum policies and asylum legislation. Second, we discuss and compare the policy tools, practices and legislation that have undermined the rights of unaccompanied Afghan minors. We also observe new tools of internal and external deterrence and restrictive asylum policies, combined with tighter border controls. In the case of adult asylum seekers from Afghanistan, high rejection rates and deportations were used for years as an important tool of deterrence. However, these tools were seldom used against unaccompanied Afghan minors before the large influx of asylum seekers in 2015. Since 2015, increased use of rejections, combined with temporary protections, have emerged as the major tools for restriction. We identify similarities and differences in the policy restrictions targeting unaccompanied minors between the countries. Although we identify some recent diverging trends in Scandinavian asylum policies regarding unaccompanied minors from Afghanistan, the general trend of policy restrictions still prevails in all three countries.
\end{abstract}

Keywords: Afghan asylum seekers, Unaccompanied minors, Scandinavian protection regimes, Temporary protection, Deterrence policy, Differential inclusion

\section{Introduction}

Scandinavian countries, especially Sweden, have traditionally had a well-established image as peaceful nations that have humanitarian asylum and refugee policies. Additionally, Scandinavian countries have been forerunners in protecting vulnerable children and fighting for their rights, both nationally and globally. Given these moral and ideological underpinnings, the notion of "the best interest of the child" has high cognitive and normative status in the Scandinavian context. In line with this ideology, unaccompanied children seeking asylum alone have traditionally been regarded as being

(c) The Author(s). 2021 Open Access This article is licensed under a Creative Commons Attribution 4.0 International License, which permits use, sharing, adaptation, distribution and reproduction in any medium or format, as long as you give appropriate credit to the original author(s) and the source, provide a link to the Creative Commons licence, and indicate if changes were made. The images or other third party material in this article are included in the article's Creative Commons licence, unless indicated otherwise in a credit line to the material. If material is not included in the article's Creative Commons licence and your intended use is not permitted by statutory regulation or exceeds the permitted use, you will need to obtain permission directly from the copyright holder. To view a copy of this licence, visit http://creativecommons.org/licenses/by/4.0/. 
especially vulnerable within Scandinavia (Hedlund 2016; Parusel 2017; Vitus and Lidén 2010; Wernesjö 2019).

The European Union (EU Charter of Fundamental Rights) and the Council of Europe have also developed a considerable acquis in the area of protection for unaccompanied minors. ${ }^{1}$ According to these institutions, unaccompanied minors are defined as an especially vulnerable group, and a set of special rights have therefore been given to this category of asylum seekers, which is in line with the United Nations Convention on the Rights of the Child. ${ }^{2}$

Although unaccompanied minors seeking asylum are protected by safeguards under international, EU and national law, it has been frequently reported that migrant children have a high risk of falling through loopholes in child protection frameworks. These children are also at a heightened risk of having their rights violated (Allsopp and Chase 2019; European Commission 2016; Hedlund 2016). Several researchers argue that the recent changes in asylum policies have contributed to undermining the rights of unaccompanied minors (De Graeve et al. 2017; Lemberg-Pedersen 2015; Lietaert et al. 2019; Wernesjö 2019).

In this article, we have chosen to focus on unaccompanied minors from Afghanistan since they have been the largest group of unaccompanied minors in Europe and Scandinavia in recent years. In line with previous studies, we assume that the recently imposed restrictive asylum policies have directly or indirectly undermined Afghan minors' rights to protection and rights of citizenship within Scandinavia. We relate our exploration to the recent influx of asylum seekers to Europe, which has often been described as a refugee or refugee crisis (Krzyżanowski et al. 2018; Sigona 2018). Large-scale migration movements, pressure on borders and recent developments in the aftermath of the "crisis" have directed new attention to migration policies within the EU, within each country and between countries. Several countries have tightened their arrangements for asylum policies, and the entire field is undergoing a major redefinition (Betts and Collier 2017; Krzyżanowski et al. 2018).

This study focuses on Sweden, Denmark and Norway's recent changes in asylum policies. On a more general level, we explore how the models and ideals of citizenship have been gradually transformed in the three countries. We believe that these changes in asylum policies and citizenship transformations have been most clearly expressed in the recent responses to unaccompanied Afghan minors.

Scandinavian countries are often categorised as being similar, falling within the same universalistic welfare regime and commonly seen as egalitarian and humanitarian (Garvik 2018; Könönen 2018). However, several researchers have shown that they also differ regarding their approach towards immigration, asylum seekers and integration policies (Brochmann and Hagelund 2012; Isaksen 2020; Valenta and Thorshaug 2013; Vitus and Lidén 2010). We will build upon these studies and provide new insights into changing reception and integration regimes in Scandinavia. The analysis is based on a desk study of policy documents, previous studies, descriptive statistics on asylum seekers

\footnotetext{
${ }^{1}$ See https://ec.europa.eu/info/policies/justice-and-fundamental-rights/rights-child/children-migration_en ${ }^{2}$ See Article 3 of the United Nations Convention on the Rights of the Child on the best interests of the child. Additionally, Article 20 focuses on children who are temporarily or permanently deprived of their family environment. See also UNHCR's Guidelines on Policies and Procedures in dealing with Unaccompanied Children Seeking Asylum February 1997 https://www.unhcr.org/3d4f91cf4.pdf
} 
and NGO reports that may indicate and clarify how changes in policies have contributed to undermining the rights of unaccompanied Afghan minors. The relevant political documents, statistics, reports and changing legal frameworks were searched for via the national authorities, EUROSTAT, IOM and on the European Commission's websites. We were also in contact with specialists within the field in Sweden, Norway and Denmark, who provided valuable clarifications and updates on recent changes in policies.

The article is structured in three parts. The first part introduces previous relevant research and our analytical approach. The second part presents basic statistics, general trends and crucial turning points regarding asylum migration to the EU and the Scandinavian countries. In the final section, policy responses, changes in institutional arrangements and policy tools in each of the Scandinavian countries are analysed and discussed.

\section{Relevant previous research}

This article aims to contribute to debates on asylum migration and the traditionally contrary considerations between "the child's best interest" framework and "migration regulation" interests. Moreover, the study sheds light on challenges regarding temporality and citizenship rights through the lens of differential inclusion (Bosniak 2007; Könönen 2018; O’Brien 2019; Owen 2019). Accordingly, this article may also contribute to the general debates on the recent developments in the asylum migration system in Scandinavia and Europe (Gammeltoft-Hansen and Tan 2017); Brekke and Staver 2018; Valenta et al. 2019). Therefore, several categories of research are relevant to this article.

The first category includes studies that show that migration policies may be inconsistent and contradictory in connection to the very specific ideas about childhood and children's rights (Hedlund 2016; Lidén et al. 2017; Parusel 2017; Valenta and Garvik 2019; Vitus and Lidén 2010; Wernesjö 2019). In these studies, the policies are often recognised as ambivalent attempts to accommodate conflicting interests. Authorities are challenged to balance human rights with national interests, as well as the principles of responsibility-sharing (Allsopp and Chase 2019; Igesund 2015; Lemberg-Pedersen 2015; Sandermann and Zeller 2017). In line with these studies, researchers have analysed how unaccompanied minors are defined and categorised in various country contexts and whether perceptions differ in light of contextual changes, time and place.

Another category of research relevant to this article includes studies that explore and compare developments in asylum policies in Europe (Brekke and Brochmann 2014; Brekke and Staver 2018; Lemberg-Pedersen 2019; Scholten and van Nispen 2015; Valenta et al. 2019). These studies explore the tools of deterrence that different countries in Europe use to deflect asylum seekers, how they position themselves in relation to each other and how they have responded to the recent increase in the influx (Triandafyllidou 2018; Valenta et al. 2019). According to these researchers, countries' policies are influenced by their local political contexts, their national interests, their geographical position and their position in the hierarchy of the European migration and asylum systems (Betts and Collier 2017; Brekke and Staver 2018; Crawley and Skleparis 2018; Triandafyllidou 2018; Valenta and Jakobsen 2020). Researchers have also focused on the interacting lines of deterrence used to curb asylum migration in times of crisis. Several tools of deterrence are proposed: (i) the policy of externalisation, (ii) border 
controls within Europe and (iii) the reduction of national standards (Valenta et al. 2019; Valenta and Jakobsen 2020). Within these policy spaces, tension becomes apparent between the desire to deflect and deter on the one hand and the obligation to protect on the other.

The third category of relevant research explores how the policy spaces of deterrence also reflect the process of differential inclusion in Scandinavian countries. The concept of differential inclusion is used to describe the selective inclusion of migrants within the sphere of rights in the receiving state (Bosniak 2007; Könönen 2018; O’Brien 2019). These researchers maintain that borders of citizenship can be constructed both outside and inside the national state. Outside borders may be expressed through denied entry, externalisation and selective inclusion regarding different categories of migrants. Inside borders may be used to provide differentiated rights and access to citizenship (Owen 2019).

We may distinguish among different degrees of citizenship and residency rights, ranging from fully legal to semi-legal to illegal (O’Brien 2019). Migrant control regimes can generate insecurity and reduced standards of citizenship by hierarchising structures and requirements towards migrants through the use of various residence permits. The asylum system divides the residence of semi-citizens into periods around which the future of one's residence is potentially at stake. A temporary or semi-legal status determines a kind of probation period in which the failure to fulfil the residence requirements can lead to legal sanctions (Könönen 2018). Goldring and Landolt (2013) call residence permit systems chutes and ladders, whereby one can climb upwards to a more secure position or slide downwards to illegality. If asylum seekers are rejected, but not deported, they can still live within a country for years. They may also flee the authorities and fall into the ranks of illegal or undocumented (non) citizens within the state.

We believe that the lenses of differential inclusion can help us to analyse and compare the recent changes in asylum policies in Sweden, Norway and Denmark. Several previous comparative studies on the inclusion of refugees and immigrants in Scandinavia assert that Denmark has been the most restrictive country, while Sweden has traditionally been the most generous, welcoming and inclusive of the three countries (Brochmann and Hagelund 2012; Garvik 2018; Isaksen 2020; Krzyżanowski 2018; Valenta and Thorshaug 2013; Vitus and Lidén 2010). Furthermore, and probably even more relevant for our analysis, Sweden has also traditionally been more reluctant to use temporary protection than Norway and Denmark, and more prone to give various rights and amnesties to asylum seekers compared to the other two Scandinavian countries (Valenta and Bunar 2010; Valenta and Thorshaug 2013).

Building on these studies, we explore the recent changes in asylum policies in Scandinavian countries. In what follows, we also scrutinise several of the proposed lines of deterrence and analyse policy responses that result in differential inclusion of asylum seekers in the Scandinavian countries. We focus primarily on the responses to an increase in the influx of asylum seekers that occurred between summer 2015 and spring 2016. This period has often been characterised by politicians and the media as the "refugee crisis" (Krzyżanowski et al. 2018; Sigona 2018; Valenta et al. 2019). Against this background, we present relevant pre-crisis policies, policies aimed at managing the crisis, and more permanent policy developments in the aftermath of the peak influx of 
2015 and 2016. We also distinguish among developments on three interdependent levels: i) the level of overall migration and asylum policy responses to "the crisis", ii) policy responses towards unaccompanied minors in general and iii) policy responses towards unaccompanied Afghan minors in particular. It is acknowledged that overall migration trends and policies do not necessarily have a direct impact on unaccompanied Afghan minors, but they may have an indirect impact (Allsopp and Chase 2019; Crawley and Skleparis 2018). By mapping general and specific policy responses and regulations in each Scandinavian country, we aim to provide knowledge of recent policy developments and to identify prevailing and diverging political strategies and tools that have had direct and indirect impacts on the rights of unaccompanied minors from Afghanistan.

\section{Migrations of unaccompanied afghan minors to Europe and Scandinavia}

Since 1999, the EU has invested considerable efforts in harmonising European asylum policies through the framework of the Common European Asylum System [CEAS]. As stated in the Policy Plan on Asylum (2008), three pillars underpin the development of the CEAS: bringing more harmonisation to standards of protection by further aligning the EU states' asylum legislation, effective and well-supported practical cooperation and increased solidarity and sense of responsibility among the EU states and between EU and non-EU countries. The EU asylum framework also claims that refugees should be granted rapid access to citizenship of the state of asylum. ${ }^{3}$

Simultaneously with an emphasis on children's rights, the EU has increased its focus on deportation and externalisation policies. The development of these types of policy instruments has been an overall trend, but recently, they have also begun to target unaccompanied minors. In 2009, the EU developed the European Return Platform for Unaccompanied Minors (ERPUM). The project aimed to organise the administrative deportation of unaccompanied minors coming from Iraq, Morocco and Afghanistan. The Scandinavian countries played a key role in the elaboration of the ERPUM project that was implemented from 2011 to 2014 (Lemberg-Pedersen 2015). However, attempts to return people to Afghanistan have been widely criticised (Allsopp and Chase 2019; Lemberg-Pedersen 2018). ${ }^{4}$

The "refugee crisis" in 2015 threw the EU and the migration regimes in several countries into disarray (Crawley and Skleparis 2018; Krzyżanowski et al. 2018; Triandafyllidou 2018). The increased number of unaccompanied minors from Afghanistan seeking asylum in Europe and Scandinavia was perceived as particularly challenging (LembergPedersen 2019; Valenta and Garvik 2019; Wernesjö 2019).

The Eurostat annual report from 2016 showed a sharp increase in the number of unaccompanied minors in 2015. This number varied between 11,000 and 13,000 in the EU over the period 2008-2013 and almost doubled in 2014 to reach more than 23,000 persons. In 2015, the number of unaccompanied asylum seekers reached more than 95 ,

\footnotetext{
${ }^{3}$ See https://ec.europa.eu/home-affairs/what-we-do/policies/asylum_en

${ }^{4}$ See https://www.reddbarna.no/nyheter/barn-sendes-tilbake-til-verdens-farligste-land; https://www.utrop.no/ Nyheter/Notiser/33457/; See also: https:/data2.unhcr.org/en/documents/download/64059; https://www. flyktninghjelpen.no/nyheter/2018/januar/afghanske-returnerte-flyktninger-moter-usikker-framtid/ Afghan authorities have also said that they cannot guarantee the safety of the repatriated people: See https://www. aftenposten.no/norge/i/glxy0/afghanistans-ambassadoer-dette-er-det-verst-tenkelige-tidspunkt-aa-sendeflyktninger-tilbake
} 
000, the highest number ever registered within the EU. ${ }^{5}$ More than half of the unaccompanied asylum applicants were Afghans. Germany seemed to be one of the largest receivers of unaccompanied minors from 2014 through 2016. However, in 2015, the highest number of unaccompanied minor asylum applicants within the EU was registered in Sweden. Figure 1 shows the arrivals of unaccompanied Afghan minors in Denmark, Sweden and Norway from 2012 to 2018.

In 2015, almost 35,300 unaccompanied minors, or $40 \%$ of all those registered in the EU member states, went to Sweden. Sweden was also the largest receiver of unaccompanied minors from Afghanistan in Europe. Of the 45,300 unaccompanied Afghan minors in the EU in 2015, 30,080 were registered in Sweden. For comparison, in 2015, Norway received 3300 unaccompanied Afghan minors and Denmark received 835. ${ }^{6}$ The gap in the number of asylum seekers may reflect the different countries' approaches towards asylum seekers before the crisis. Denmark and Norway have promoted strict asylum policies for several years, while Sweden has been more welcoming (Brochmann and Hagelund 2012; Krzyżanowski 2018). The above-described migration trends are relevant to this article, as it is often believed that the receiving countries often use restrictive asylum policies in periods with an increased influx of asylum seekers. ${ }^{7}$ However, as we will discuss later, the size of the influx may not necessarily reflect the different countries' policy responses.

\section{Tensions between deterrence and protection: the afghan case}

Several scholars assert that borders are not designed only to keep out unwanted foreigners. Borders also follow asylum seekers into the national space through legal status and reflect the aims of states to redefine the deservingness of citizenship (Könönen 2018; O’Brien 2019; Squire et al. 2017; Wernesjö 2019). The recent developments in Scandinavian policies towards unaccompanied minors from Afghanistan should be seen in this context. It can be argued that the responses to the influx of Afghan minors in 2015 may represent a paradigm shift in the Scandinavian authorities' approach to inclusion and obligation to children in migration. Before 2015, it was relatively easy to obtain protection and full citizenship in Scandinavian countries for Afghan asylum seekers, especially for those who arrived as unaccompanied minor asylum seekers. However, the stance towards asylum seekers from Afghanistan has changed in recent years.

The political and legal framework provided by the EU, international obligations and conditions within Afghan society are relevant to understanding Scandinavian responses to the influx of unaccompanied minors from Afghanistan. According to the EU and the different Scandinavian immigration acts $^{8}{ }^{8}$ the basis for being recognised as a refugee

\footnotetext{
${ }^{5}$ There is considerable uncertainty regarding these statistics. The actual number may be significantly higher. It is very difficult to obtain accurate numbers for unaccompanied and separated children, as formal registration procedures in some countries in Europe do not allow their identification; see https://www.iom. int/sites/default/files/press_release/file/IOM-UNICEF-Data-Brief-Refugee-and-Migrant-Crisis-in-Europe-3 0.11.15.pdf.

${ }^{6}$ Most of these were boys aged between 16 and 17 (Eurostat 2016).

${ }^{7}$ It is often suggested that the receiving countries use the restrictions in asylum policies and increase rejection rates as a tool of deterrence (Brekke et al. 2016; Valenta et al. 2019).

${ }^{8} \mathrm{See} \mathrm{https://www.migrationsverket.se/Andra-aktorer/Kommuner/Om-ensamkommande-barn-och-ungdomar/}$ Lagar-och-forordningar.html, https://lovdata.no/dokument/NL/lov/1992-07-17-100/KAPITTEL_6\#\%C2\%A75 a-3, https://danskelove.dk/udl\%C3\%A6ndingeloven
} 


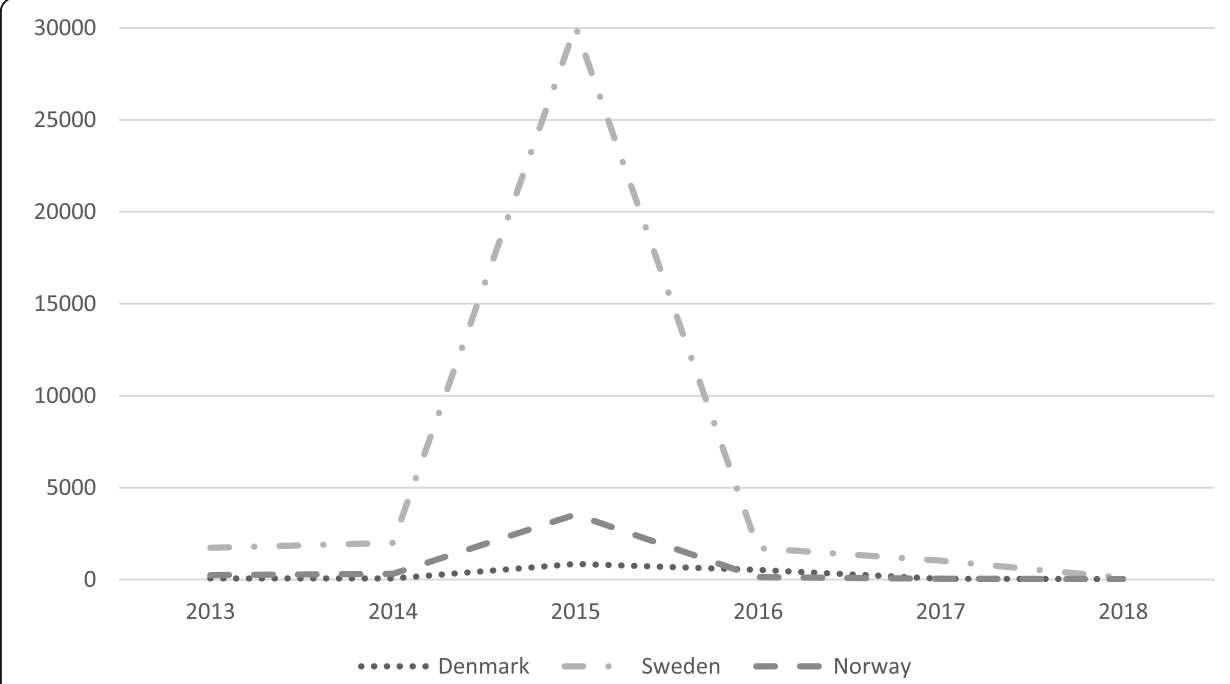

Fig. 1 Unaccompanied Afghan Asylum Applicants in Scandinavia 2013-2018 (Source: own compilation based on data from Udlæningestyrelsen (2018), Migrationsverket (2018) and UDI (2019).)

(obtaining refugee determination status) is that one has a well-founded fear of being subjected to persecution because of ethnicity, descent, skin colour, religion, nationality, membership in a special social group or political perception. The law further states that an individual can also be granted protection without being classified into the abovementioned categories if the individual is in real danger of being subjected to the death penalty, torture or other inhuman or degrading treatment or punishment upon return home. ${ }^{9}$ The EU Charter of Fundamental Rights (2012/C 326/02) further states that safety and the principle of the best interests of the child should be the main concern. ${ }^{10}$

Although Afghans represent the second-largest refugee population globally, in recent years, they have been denied asylum status more often than not on the abovementioned grounds in both the EU and Scandinavia. ${ }^{11}$ In August 2018, the UNHCR Eligibility Guidelines for Assessing the International Protection Needs of Asylum Seekers from Afghanistan were published. The report considered the trends in the security situation of Afghanistan. Given the overall situation of conflict and human rights violations and the adverse impact on the broader socio-economic context, UNHCR claimed that neither the internal flight alternative nor the internal relocation alternative (IFA/IRA) was generally available in Kabul. Several NGOs and experts have also questioned whether the different migration authorities have correctly assessed the security situation in Afghanistan (Amnesty International 2018; Hall / NRC / IDMC 2018; Majidi 2017; Save the Children 2018).

European countries still disagree about whether migrants from Afghanistan should be entitled to asylum. Consequently, the recognition and rejection rates of Afghan asylum seekers have varied within the EU and among Scandinavian countries. For instance, in 2015, Sweden recognised 74\% of Afghan asylum applicants as needing international protection, whereas only 38\% were recognised in Denmark (Migrationsverket 2014;

\footnotetext{
${ }^{9}$ Council of the European Union, Directive 2011/95/EU https://eur-lex.europa.eu/legal-content/EN/TXT/ ?uri=celex\%3A32011L0095

${ }^{10}$ See https://eur-lex.europa.eu/legal-content/EN/TXT/?uri=CELEX:12012P/TXT

${ }^{11}$ See https://www.unhcr.org/statistics/unhcrstats/5b27be547/unhcr-global-trends-2017.html
} 
Udlæningestyrelsen 2017). The average recognition rate for Afghans within the EU-28 was $42 \%$ in the fourth quarter of the same year (Eurostat 2018).

The share of rejections among Afghan asylum applicants increased substantially in the period 2014-2018. In addition to higher rejection rates, the share of subsidiary protection status was relatively high (Eurostat 2018). At the EU-28 level, there are few available statistics collected in a comparable manner on unaccompanied minor asylum applicants. However, it is possible to identify increased rejection rates after 2015 in Scandinavian countries. Additionally, we can identify a more widespread use of temporary protection statuses (Migrationsverket 2018; UDI 2018; Udlæningestyrelsen 2018). Very few of the unaccompanied Afghan minors seeking asylum in Scandinavia in 2015 had valid ID documents. ${ }^{12}$ Conditions in Afghanistan have also problematised family tracing and possibilities for family reunification in Afghanistan (Parusel 2017; Wernesjö 2019). Accordingly, temporary protection status was used, since it was extremely difficult to return unaccompanied minors to Afghanistan.

The above-mentioned factors have contributed to intensifying the ambivalences and tensions between protection- and deterrence-related concerns. Authorities' concerns regarding the increased influx, together with concerns about the sustainability of returns to Afghanistan and obligations regarding the protection of children in migration, may explain the changes in the types of permits granted to Afghans.

In the next three sections, we explore in detail the Danish, Swedish and Norwegian policy responses to the influx of asylum seekers. We distinguish among responses before, during and after the refugee crisis of 2015, when the Scandinavian countries faced a record-high influx of asylum seekers. Furthermore, we distinguish several categories of responses and "the tools of deterrence" (Triandafyllidou and Dimitriadi 2014; Valenta et al. 2019). Here, we will analyse and discuss changes in considerations regarding subsidiary protection and "differential inclusion" within the frame of deterrence and universalism. First, we explore the general policy responses to the increased influx. Thereafter, we investigate policy responses towards unaccompanied minors, particularly those that have had an impact on differential inclusion of Afghan minors.

\section{The Danish policy responses}

Before the so-called "refugee crisis", the Danish legislation operated with three different types of statuses for their resident permits: i) convention status (Article 7 (1)), ii) protected status (Article 7 (2)) and iii) temporary protected status (Article 7 (3)). A residence permit following recognition under convention status was granted for a maximum of 2 years at a time, while protected status was granted for a maximum of 1 year and for a maximum of 2 years at a time after 1 year. Temporary status was granted for a maximum of 1 year and for a maximum of 2 years at a time after 3 years. ${ }^{13}$ Hence, temporality has been a hallmark of the Danish asylum regime for several years, including before the influx of 2015. This approach was characterised as highly controversial by several researchers who have asserted that temporary protection contradicts the traditional perception of universal welfare states employing a hard outside and soft inside approach towards migrants (Bosniak 2007; Könönen 2018).

\footnotetext{
${ }^{12}$ https://landinfo.no/wp-content/uploads/2018/03/Afghanistan-Tazkera-pass-og-andre-ID-dokumenter-20022 018.pdf

${ }^{13}$ https://www.asylumlawdatabase.eu/en/content/country-profile-denmark\#application
} 
Looking into Danish policies, the state has indeed promoted a strict line towards asylum seekers both "outwards" and "inwards" over the last decade. These policies have differentiated the position and rights of semi-legal citizens and non-citizens. Regarding tools facing "outwards", authorities have focused on the externalisation of migration policies and the deportations of rejected asylum seekers. They have also invested in information campaigns in the sending countries and tightened border controls. Measures facing "inwards" have included raising the threshold for obtaining protection, reducing the time limits of temporary protections, stricter identification requirements and various restrictions to the right to work (Valenta and Thorshaug 2013).

In the year of "the refugee crisis", Denmark was also at the forefront of the European countries that presented strict policy arrangements and tools. In their efforts to reduce the number of asylum seekers, Denmark authorities sought a further tightening of asylum regulations and raised the threshold of access to Denmark. Accordingly, the government developed the "Asylum Package" (2015), which included several tools and instruments to achieve the goal of restriction. The package provided policy measures in line with all the previously mentioned "tools of deterrence" (Triandafyllidou and Dimitriadi 2014; Valenta et al. 2019). The most visible and "outward" policy tool was their call for national border control. A so-called "emergency brake" was implemented in autumn 2015. According to this law, asylum seekers could be rejected directly at the border and thus would not be allowed to process their asylum application in Denmark. The emergency brake was intended to be activated only in a "crisis" situation, in which the Dublin regulation was considered to have ceased to function. These restrictions were quite radical, as they clearly undermined the principle of non-refoulment and conflicted with the 1951 Refugee Convention.

In the period of increased influx, the Danish border controls with Germany were reintroduced. Although they were introduced as temporary measures, the border controls were maintained in the post-crisis period, and additional restrictive policies were introduced. The focus was on reception standards, asylum seekers' rights and return programmes. For example, throughout 2016-2018, further limitations were placed on the duration of residence permits for persons with a need for protection. Simultaneously, the Danish government strengthened the area of return and readmission. A special Return Unit under the Ministry of Immigration and Integration was established in April 2016, and the Ministry of Foreign Affairs appointed an ambassador to support the government's approach to returns and readmission.

Furthermore, Denmark increased the detention of refused asylum seekers. The government implemented shorter exit deadlines, stricter controls in departure centres and more consistent use of notification and residence duties. Increased controls and sanctioning tools were implemented together with a decrease in integration arrangements, such as teaching, training activities, advice and guidance services. ${ }^{14}$ Accordingly, the reduced national standards increased the gap between full citizenship rights (insiders) and the citizenship provided for asylum seekers with subsidiary protection permits (semi-citizens). For the rejected, but not deported (non-citizens), civil rights were reduced to a basic minimum. Hence, national standards were also reduced in line with the logic of deterrence (Triandafyllidou and Dimitriadi 2014; Valenta et al. 2019).

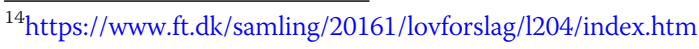


The Danish asylum and temporary protection regime does not just distinguish between insiders and outsiders. The regime has also produced lines of strong and weak membership and therefore also borders between different categories and groups within the welfare state (Bosniak 2007; Könönen 2018; O’Brien 2019). The most recent restrictions were introduced on February 21, 2019, when the government, the Danish People's Party and Social Democracy, voted through new legislative restrictions, the so-called Paradigm Shift Act (Act 140). ${ }^{15}$ Act 140 came into force on March 1, 2019, and contained amendments to several laws, including in particular the Aliens Act, the Integration Act, the Act on Active Social Policy and the Repatriation Act. In the Aliens Act, the wording of $\mathbb{} 7$ and $\mathbb{8}$ was changed, clarifying that every residence permit given to refugees should only be granted temporarily and that temporary permits should also apply to quota refugees. In addition to increased rejection rates and temporary protection status, the Danish government reduced the potential for family reunifications. ${ }^{16}$ It was emphasised that the main rule in relation to the residence permits of refugees and family reunifications should be withdrawn or exempted when possible. Moreover, the government proposed the creation of a position in the ministry to focus on the withdrawal of residence permits granted for humanitarian reasons. ${ }^{17}$

The policies constructed as a response to the crisis have now been reinforced and implemented as permanent policy instruments. ${ }^{18}$ The new policies have limited people's entry into the Danish territory, in practice, creating a wall against third-national migrants. Simultaneously, the reduction of national standards has also contributed to an increase in the gap of rights between nationals and second-class semi-citizens within Denmark.

\section{The Danish policy response to unaccompanied minors from Afghanistan}

The above-described policy instruments and restrictions were not specifically directed at unaccompanied asylum seekers from Afghanistan. Most of them targeted all asylum seekers, especially adults. However, they also affected unaccompanied asylum seekers by reducing their access to Danish territory. They also provided a framework for a temporary protection regime that was later used towards unaccompanied asylum seekers from Afghanistan.

The principles for processing asylum requests from unaccompanied minors remained roughly the same from 1993 to January 2010 (Lemberg-Pedersen 2015). Until 2010, unaccompanied minors were described as being particularly vulnerable and in need of special treatment. They could also be granted protection permits in Denmark for reasons other than those that applied to adult asylum seekers (Lemberg-Pedersen 2015).

In line with the CEAS, Denmark proposed amendments to the legislative framework for unaccompanied minors in 2009. In 2010, the government began to depart from the permanent protection regime and increased its emphasis on temporary protection of

\footnotetext{
${ }^{15}$ See https://www.ft.dk/samling/20181/lovforslag/l140/index.htm

${ }^{16}$ The restriction of family reunification was also motivated by European law in the area, see http://www. europeanmigrationlaw.eu/documents/COM(2019)162-FamilyReunion.PDF

${ }^{17} \mathrm{~A}$ humanitarian residence permit may be withdrawn if circumstances that have justified the residence permit have changed in such a way that the foreigner no longer risks persecution (\$19-1, LBK nr 1022).

${ }^{18}$ Recently, the new Danish prime minister has also suggested implementing the possibility of border rejection (the emergency brake) as a permanent policy tool https://www.socialdemokratiet.dk/media/8545/ retfaerdig-og-realistisk-ny.pdf
} 
unaccompanied minors (L37 2010). ${ }^{19}$ This practice was a response to increased arrivals of unaccompanied minors, especially from Afghanistan. ${ }^{20}$

Before the crisis, the rejection rate of unaccompanied minors was relatively low. In 2014, most unaccompanied minors received protection. For example, in 2014, 40 (21\%) of a total of 192 asylum applicant decisions for unaccompanied minors were rejected. During the crisis, we can observe an increased use of temporary permits, while in the aftermath of the crisis, the largest share was rejected. In 2017, the rejection rate increased to 61\% (387 total decisions), and it was as high as 67\% in 2018 (102 total decisions). According to the Refugee Council, rejected unaccompanied minors from Afghanistan risked deportation after they reached the age of $18 .^{21}$

As a rule, unaccompanied minors must now meet the same requirements as adult asylum seekers to obtain protection in Denmark. To be granted an extension, the unaccompanied minor must continue to meet the requirements of either Article 9c (3) (i) or (ii). Every temporary residence permit expires when the child turns 18, after which the youth must normally leave Denmark. However, when the residence permit is about to expire, the unaccompanied minor can apply for an extension. Hence, in cases of exceptional circumstances, a residence permit may be granted after the age of 18, although it is always temporary (Aliens Act Article $9 \mathrm{c}, 1$ ). ${ }^{22}$ If the return is not undertaken voluntarily, the Danish authorities will plan for a forced return undertaken by the Danish National Police. If it is not possible to return the asylum seeker, he or she will be obliged to reside at one of two departure centres.

Because of the difficult security situation in Afghanistan, it is not easy to deport young adults and safeguard international law and human rights standards at the same time (Lemberg-Pedersen 2015). Given its international obligations (such as Directive 2008/115/EC), Denmark has committed itself to protecting children who are without a family network or without any possibility of staying at a reception and care centre in their country of origin. ${ }^{23}$ However, when unaccompanied minors with temporary protection turn 18, they become adults and are targeted by all of the above-described general policy restrictions. ${ }^{24}$ Categorised as rejected, but not deported, young adults are forced to live in Denmark as non-citizens with harsh restrictions and limited social rights. Consequently, unaccompanied Afghan minors stranded in the state of differentiated inclusion have lived in a no man's land between semi-legality and illegality for years.

\section{The Swedish policy responses}

Traditionally, Sweden has been perceived as a particularly immigrant-friendly and open-minded country in the European context and compared to its Scandinavian neighbours (Green-Pedersen and Krogstrup 2008; Isaksen 2020; Krzyżanowski 2018; Neumayer 2004; Valenta and Bunar 2010). However, we can observe a change to a more restrictive asylum policy in Sweden, starting with amendments of the Alien Act

\footnotetext{
${ }^{19}$ See https://www.ft.dk/samling/20101/lovforslag/l37/index.htm

${ }^{20}$ See https://www.ft.dk/ripdf/samling/20101/lovforslag/137/20101_137_betaenkning.pdf

${ }^{21}$ See https://fyens.dk/artikel/dansk-flygtningehjælp-færre-afghanere-får-asyl-mens-volden-stiger-i-afghanistan

${ }^{22}$ See https://www.nyidanmark.dk/da/Applying/Asylum/Unaccompanied\%20minor

${ }^{23}$ Directive 2008/115/EC of the European Parliament and of the Council of 16 December 2008 on common standards and procedures in Member States for returning illegally staying third-country nationals.

${ }^{24}$ Among others, this includes a reduction in reception standards, detention and deportation.
} 
in 2010 (CEAS). ${ }^{25}$ Furthermore, in 2012, Sweden implemented a legal reform that increased the authorities' ability to provide subsidiary permits. Nevertheless, until 2016, Sweden still had one of the most open migration policies within Europe (Bech et al. 2017; Krzyżanowski 2018).

In 2015, Sweden faced a large increase in the number of asylum seekers, and in autumn 2015, a new Temporary Alien Act was proposed. The new legal framework came into force on July 20, 2016, ${ }^{26}$ and covered only the minimum level of the EU asylum standard. The temporary law introduced changes such as (i) fewer protection grounds, (ii) temporary residence permits as a rule, (iii) limited opportunity for family reunification and (iv) strengthened supply requirements for family reunification (Lag 2016, p. 752). The restrictions of the new temporary law clearly reflected the deterrence line of reducing national standards. ${ }^{27}$ These new policies contrasted with the traditional Swedish practice, emphasising the right to secure and predictable residence within the welfare state (Krzyżanowski 2018). The Swedish response to the crisis also established legal hierarchies in the distribution of public resources. Limited access to welfare services contributed to the formation of asymmetrical social relations inside the society, or what Könönen (2018) calls the process of "differential inclusion of non-citizens in a universalistic welfare state."

The Swedish Temporary Alien Act of 2015 has three types of protection statuses: i) refugee status declaration, ii) subsidiary protection and iii) person otherwise in need of protection. Convention refugees should be granted a three-year temporary permit with the right to family reunification. Before the law was introduced, the normal practice in Sweden was to provide permanent permits to this category of asylum seekers (Wernesjö 2019). Hence, the new legal framework has turned Sweden's asylum policies in the direction of temporariness. The changes represent a clear shift away from the more permanent perspective of resettlement and belonging that were the hallmarks of the Swedish protection ideology for decades (Bech et al. 2017; Green-Pedersen and Krogstrup 2008; Valenta and Bunar 2010). ${ }^{28}$

According to the law of 2016, beneficiaries of subsidiary protection should be granted an initial period of 13 months for a temporary residence permit with no right to family reunification. The permit could be extended for another 2 years if protection grounds persisted. Moreover, the temporary residence permit provided the right to live and work in Sweden for the duration of the permit. The third type of protection status could only be given to children and families with children who applied for asylum before November 24, 2015.

In addition to greater temporariness, the Swedish authorities became more restrictive in their assessment of protection needs. The Swedish case clearly shows how the

\footnotetext{
${ }^{25}$ Sweden's Alien Act was amended in 2010 with the aim of better reflecting the EU directives of a common European asylum system. See https://ec.europa.eu/home-affairs/what-we-do/policies/asylum_en

${ }^{26}$ See https://www.riksdagen.se/sv/dokument-lagar/dokument/svensk-forfattningssamling/lag-2016752-omtillfalliga-begransningar-av_sfs-2016-752

${ }^{27}$ Further, the temporary framework allowed the Swedish authorities to enforce stricter border control. Border controls at the border with Denmark were reintroduced as a direct response to an increase in the numbers of asylum seekers coming to Sweden from that border. See https://euobserver.com/migration/131 078

${ }^{28}$ The temporary act of 2016 also introduced medical age tests for unaccompanied minors. Prior to the mass influx, the Swedish authorities were very reluctant to make use of this tool. The Swedish authorities have criticised other countries' practices due to this type of testing (Wernesjö 2019).
} 
assessment of who needs protection can change drastically within a short time. Statistics on Swedish asylum decisions issued to Afghan asylum applicants illustrate this fact. For example, in 2014, 92\% of Afghan applicants were granted protection (Migrationsverket 2014). In 2017, the share of positive asylum applicant decisions was reduced to 38\% (Migrationsverket 2017). The UNHCR has recently defined the security situation in Afghanistan during that same period to have been more unstable than before (UNHCR 2018). Hence, the rejection rates do not reflect improved safety for Afghans in their home country. Instead, they illustrate how pressure on borders may have a considerable impact on the nation state's exercise of balancing protection needs, its deterrence policy and migration regulation considerations. The statistics also highlight the dilemma of responsibility-sharing and the challenge of diverging from restrictions implemented by other countries (Triandafyllidou and Dimitriadi 2014; Valenta et al. 2019).

In recent years, Sweden has also increased its focus on the return of rejected asylum seekers. In 2018, Sweden and Austria (leading the working group on harmonisation) became partners in the European Return and Reintegration Network. The programme aimed to strengthen, facilitate and streamline the return process in the EU through common initiatives. The aim was also to promote durable and efficient reintegration to countries outside the EU. ${ }^{29}$

It can be argued that the increased focus on the inward and outward measures of deterrence, such as high rejection rates, subsidiary protection regimes, the introduction of border controls and the increasing pressure of return, have gradually transformed and undermined the Swedish identity and image as a safe port for those in need of international protection. It seems that this shift does not represent a temporary divergence from the relatively liberal stance Sweden has been known for (Valenta and Bunar 2010). Instead, it seems to represent the start of a long-term restrictive trend. The temporary law framework implemented in 2015 was, for example, intended to be valid only until July 19, 2019. However, with the January agreement (2019), ${ }^{30}$ the government extended the act for another 2 years. The decision to do so was a result of government negotiations among the Social Democrats, the Centre Party, the Liberals and the Environment Party (Miljöpartiet) after the 2018 parliamentary election. The new government constellation also established a parliamentary committee to investigate how Sweden's asylum legislation should be shaped for the future. ${ }^{31}$

\section{The Swedish policy response to unaccompanied minors from Afghanistan}

Until July 20, 2016, most of the residence permits granted to unaccompanied minors in need of protection or on humanitarian grounds were permanent (Migrationsverket 2014). ${ }^{32}$ However, the Temporary Alien Act proposed that temporary residence permits should be introduced for certain categories of asylum seekers, including

\footnotetext{
${ }^{29}$ See https://easo.europa.eu/easo-annual-report-2018/4101-unaccompanied-minors\#ar785

${ }^{30}$ See https://www.regeringen.se/tal/20192/01/regeringsforklaringen-den-21-januari-2019/

${ }^{31}$ See https://www.socialdemokraterna.se/globalassets/aktuellt/utkast-till-sakpolitisk-overenskommelse.pdf . On 15 September 2020, the chairman of the parliamentary migration committee submitted the report: A long-term sustainable migration policy (SOU 2020: 54) to the Minister of Justice and Migration. However, it has not yet (November) been announced what the continued decision-making process will look like. ${ }^{32}$ See https://www.migrationsverket.se/download/18.7c00d8e6143101d166d1aad/1485556214929/Avgjorda\%2 Oasylärenden\%202015\%20-\%20Asylum\%20desicions\%202015.pdf
} 
unaccompanied minors. According to the proposal, those who received refugee status were granted a residence permit for 3 years with the possibility of renewal for 1 year. A person who received alternative protection status was granted a residence permit for 13 months. Hence, the temporary law removed the possibility of issuing permanent residence permits for refugees and those with alternative protection needs.

Like Denmark and Norway, Sweden responded with several tools of deterrence directed towards unaccompanied minors from Afghanistan. The rejection rates for unaccompanied asylum seekers from Afghanistan were relatively low prior to the large influx of 2015. In 2014, there were a total of 968 asylum applicant decisions, and the vast majority received protection (Migrationsverket 2014). At the peak of the crisis in 2016, the rejection rates almost tripled. In the "post-crisis period", which was characterised by a low influx, the rejection rates remained high. For instance, in 2018, unaccompanied minors from Afghanistan received 194 rejections. There were 689 decisions in total, which means that the rejection rate was four times higher than before the crisis (Migrationsverket 2018).

Regarding protection, we have also seen a clear increase in the use of temporary protection status in the case of unaccompanied minors. Prior to the crisis, very few unaccompanied asylum seekers received temporary protection. For example, in 2014, only three temporary protections were provided (of 3269 positive decisions). At the peak of the crisis in 2016, we can observe a huge increase in the number of temporary protections: 3775 subsidiary protections were granted, which amounted to more than half of all protections. The same trend continued after 2016. For example, in 2018, 864 unaccompanied asylum seekers received protection, and 523 of them were granted subsidiary/temporary status (Migrationsverket 2018).

Unaccompanied minors with a temporary permit status lack the ability to plan their futures and to make choices about the direction of their lives. They are situated in a condition of social and civic limbo, unable to commit to building a new life because they may be returned to their old one. This treatment of unaccompanied minors has been widely criticised in Sweden and may explain why the government implemented various exceptions and concessions in the new legislation (Wernesjö 2019).

As in Denmark (and Norway, as we will soon see), the temporary permits were intended to grant unaccompanied minors the right to stay in Sweden until they turned 18. However, unaccompanied minors who were already in the asylum process were exempted from this new scheme. Unaccompanied children who applied for asylum as of November 24, 2015 had their cases assessed according to the previous law. This meant that they could be granted permanent residence permits if their claims were successful. The exception rule was estimated to include approximately 50,000 children. ${ }^{33}$

Another concession given to unaccompanied minors with temporary protection in Sweden was the so-called High School Act introduced in 2017. The High School Act is a part of the Temporary Act (2016) and not the general framework (2005 Aliens Act still in force). However, the new High School Act came into force on July 1, 2018. ${ }^{34}$

\footnotetext{
${ }^{33}$ However, a child who had turned 18 when the case was decided would not benefit from this concession See https://www.regeringen.se/pressmeddelanden/2016/02/forslag-om-att-tillfalligt-begransa-mojligheten-attfa-uppehallstillstand-i-sverige/; See also http://www.asylumineurope.org/reports/country/sweden/contentinternational-protection/status-and-residence/residence-permit ${ }^{34}$ See https://www.regeringen.se/4950ea/contentassets/7bdc911cabaf49eea36c3ac9b5247026/ny-mojlighet-tilluppehallstillstand.pdf
} 
The new act was intended to cover all nationalities, but was constructed to address the young Afghans who applied for asylum in Sweden in $2015 .{ }^{35}$ To be covered by the High School Act, an individual had to be waiting for at least 15 months for a decision by the Migration Board and had to have turned 18 during that time. Further, the individual had to have applied for asylum before November 25, 2015, when the temporary asylum law was announced. Finally, individuals were covered by the High School Act if they received the decision after June 22, 2016, when the temporary law came into force. ${ }^{36}$

The law was intended to give a new opportunity for unaccompanied minors to stay in Sweden if they had studied there (Lag 2017, p. 353). If these asylum seekers went to school and then obtained a job within 6 months of completing their studies, they could stay in Sweden. By the deadline in September 2018, the Swedish authorities had received nearly 12,000 applications. In January 2019, 5200 youths were granted residence permits according to the law, but almost 2500 were rejected. There are still trials of approximately 3500 high school cases in the courts. ${ }^{37}$

The High School Act can be considered a softening of the political response towards Afghan minors who arrived in 2015. Ultimately, the act can be perceived as a governmental strategy to delay difficult solutions or to manage the dilemma of return. The new legal framework does not guarantee Afghan youths a future in Sweden. However, the youths who have been granted high school permits have considerably increased their chances of staying. ${ }^{38}$ Accordingly, they have been given the chance to struggle upwards to a more secure position of citizenship. On the other hand, if they fail, they may slide downwards to illegality (Goldring and Landolt 2013).

\section{The Norwegian policy responses}

Norway had relatively strict asylum seeker policies several years before the migration crisis of 2015. Since the Immigration Act was passed in 2009, Norway has had a provision to provide subsidiary permits and to revoke refugee status. The provision in Section 37 of the Immigration Act reflects the Refugee Convention Articles 1C (5) and (6). Similar provisions can be found in the EU Status Directive. However, these provisions were rarely used in Norway before the record influx of 2015.

In September 2015, several thousand asylum seekers arrived in Norway by crossing the Norway-Russian border. According to the Police Immigration Unit, approximately one-third of the asylum applicants reported that they came from Syria, while another third reported coming from Afghanistan. ${ }^{39}$ The Norwegian government responded rapidly and implemented legislative restriction amendments. For instance, the amendment of the possibility of rejection at the Norwegian border entered into force on November

\footnotetext{
${ }^{35}$ See https://www.svt.se/nyheter/inrikes/klart-9-000-ensamkommande-far-ny-chans-att-stanna-i-sverige; See also https://www.expressen.se/nyheter/qs/de-9-000-afghanerna\%2D\%2Dvilka-ar-de-egentligen/

${ }^{36} \mathrm{See} \mathrm{https://www.migrationsverket.se/Andra-aktorer/Kommuner/Om-gymnasielagen.html}$

${ }^{37}$ See https://www.migrationsverket.se/Om-Migrationsverket/Pressrum/Nyhetsarkiv/Nyhetsarkiv-2019/201901-15-Over-5-000-har-hittills-fatt-uppehallstillstand-enligt-nya-gymnasielagen.html

${ }^{38}$ The legal criticism of this process has partly argued that the law was difficult to interpret and partly that earlier requirements to be able to prove the minor's identity were mitigated. In the current legal text, it is stated that residence permits may be granted even if the minor's identity is unclear and he or she cannot make his or her identity probable (https://www.expressen.se/kvallsposten/just-nu-migrationsdomstolenkritiserar-nya-gymnasielagen/).

${ }^{39}$ See https://www.udi.no/statistikk-og-analyse/arsrapporter/tall-og-fakta-2015/faktaskriv-2015/hvor-mangesokte-om-beskyttelse/
} 
20, $2015 .^{40}$ Accordingly, Norway was the first Scandinavian country to implement this tool of deterrence as a response to the crisis (GI-12/2015; GI-13/2015).

In 2016, further restrictions were implemented in two packages: amendments to the Immigration Act - Restrictions I (September 2016) and II (October 2016). ${ }^{41}$ The legislative framework i) gave the Ministry of Justice and Emergency Affairs expanded instructional authority over the Immigration Appeals Board and ii) extended provisions of the right to refuse to assess an asylum application and an extended use of coercive means. ${ }^{42}$ In addition, temporary border controls to other Schengen countries that were reintroduced during the period of the high influx of asylum seekers in 2015 were maintained in the period of low influx. The most recent reintroduction of temporary border control was meant to last from May to November 2019, and included all international borders, with an initial focus on ferry connections with Denmark, Germany and Sweden. ${ }^{43}$

The Norwegian government also implemented an internal flight alternative and the internal relocation alternative (IFA/IRA) in their legal framework. ${ }^{44}$ Thus, according to the new Alien Act, asylum seekers could be returned to places in their country of origin where they did not have a network or connection. These changes allowed the Norwegian authorities to return many rejected asylum seekers to Afghanistan. ${ }^{45}$ Consequently, Norway conducted the highest number of forced returns to Afghanistan among all European countries in 2016. ${ }^{46}$

There was a drastic reduction in the influx and asylum applicant decisions in the period after 2015 (from 4325 in 2015 to just 125 decisions in 2018). Nevertheless, the Norwegian authorities have maintained their restrictive stance towards asylum seekers. In 2018, the Norwegian government declared that it wanted to use Norway's position as an aid provider to secure more return agreements. ${ }^{47}$ Norwegian authorities have also contributed strongly to several FRONTEX operations in efforts to curb irregular migrations and strengthen the Schengen borders. ${ }^{48}$

\section{The Norwegian policy response to unaccompanied minors from Afghanistan}

The Norwegian government has been eager to implement new legislative frameworks and directives provided by the European Commission. Accordingly, Norway was the first Scandinavian country to implement Directive 2004/83/EC in 2009. ${ }^{49}$ Hence, the Norwegian authorities expanded their ability to use subsidiary permits. However, the

\footnotetext{
${ }^{40}$ See https://www.regjeringen.no/no/dokumenter/prop.-16-1-20152016/id2461221/sec1

${ }^{41}$ See https://www.udiregelverk.no/no/nyheter/endringer-i-utlendingsloven-innstramninger-ii/

${ }^{42}$ See https://stortinget.no/no/Saker-og-publikasjoner/Publikasjoner/Innstillinger/Stortinget/2015-2016/inns-2 01516-391/?lvl=0\#a1

${ }^{43}$ For more, see https://ec.europa.eu/home-affairs/what-we-do/policies/borders-and-visas/schengen/ reintroduction-border-control_en

${ }^{44}$ See https://www.udiregelverk.no/no/rettskilder/udi-praksisnotater/pn-2014-004/

${ }^{45}$ The Norwegian authorities defined Syria as not returnable, while certain parts of Afghanistan were considered safe. See https://www.vg.no/nyheter/innenriks/i/52AEW/den-nye-asylavtalen-her-er-de-18punktene

${ }^{46}$ Numbers from the Policy Immigration Unit on forced deportations in 2015, 2016 and 2017. Available from https://www.politiet.no/aktuelt-tall-og-fakta/tall-og-fakta/uttransporteringer/ http://appsso.eurostat.ec.europa. eu/nui/submitViewTableAction.do

${ }^{47}$ See https://www.bistandsaktuelt.no/nyheter/2018/regjeringen-varsler-reform/

${ }^{48}$ See https://www.regjeringen.no/no/tema/innvandring/innsikt/schengen\%2D\%2Dog-dublin-samarbeidet/id5 $78315 /$

${ }^{49} \mathrm{See}$ https://eur-lex.europa.eu/legal-content/EN/TXT/PDF/?uri=CELEX:32004L0083\&from=RO
} 
option of providing temporary residence permits to unaccompanied minors was rarely put into force until 2016.

Like Denmark and Sweden, the Norwegian overall policy response to the crisis was to adjust the legal framework in line with the minimum requirements of international commitments. Nevertheless, the Norwegian Alien Act emphasised taking the child's perspective into consideration when assessing whether there was a need for protection. ${ }^{50}$ Hence, the consideration of the best interests of the child had to be properly assessed and tried against other considerations that applied. Nevertheless, according to the Alien Act, this did not imply that the interests of the child would necessarily become crucial (Prop. 90 L (2015-2016)).

According to the Alien Act, the asylum applicant's age at the time of the decision was used in the assessment of whether the unaccompanied minor would be granted a residence permit. If the minor was under the age of 18 when applying for asylum but turned 18 before the decision was made, the minor was treated as an adult asylum seeker. Unaccompanied minor asylum seekers with family members in Norway could apply for family reunification. However, in these cases, the consideration of the child's best interest needed to be weighted more heavily than Norway's right to regulate migration. ${ }^{51}$

Due to an increase in the number of unaccompanied asylum seekers, the Norwegian authorities also began the practice of granting temporary protections, which in practice were postponed rejections. If the applicant was over 16 years old at the time of the asylum decision, the permit could be limited by giving it a duration until the child reached the age of 18 (Alien Act, section 8-8). Due to the lack of a repatriation agreement with Afghanistan, Norway was restricted by the international obligation to return children without proper care to their country of origin. The Norwegian authorities considered that most of the unaccompanied Afghan minors would be in such a situation if they were returned as children.

In the case of unaccompanied Afghan minors, the dilemma between children's rights and migration regulatory considerations became very visible. Accordingly, the authorities tried to redefine the meaning of children's best interests by emphasising the importance of family relations, preventing dangerous journeys and avoiding the use of anchor children (Allsopp and Chase 2019; Sandermann and Zeller 2017; Wernesjö 2019). By reconceptualising the child's best interest, the authorities tried to legitimate the changes in policies towards unaccompanied Afghan minors in the wake of the crisis. $^{52}$

As in Sweden, almost every unaccompanied minor from Afghanistan was granted permanent protection in Norway before 2016. For example, in 2014, unaccompanied Afghan minors received 202 decisions, of which three were rejected and five received temporary or limited protection status. However, the rejection rates increased after 2015. Furthermore, we can observe an increase in the number of temporary protection

\footnotetext{
${ }^{50}$ See UNHCR Guidelines on Determining the Best Interest of the Child; UNHCR Guidelines on International Protection: Child Asylum Claims under Articles 1(A)2 and 1(F) of the 1951 Convention and/or 1967 Protocol relating to the Status of Refugees.

${ }^{51}$ See https://stortinget.no/no/Saker-og-publikasjoner/Publikasjoner/Innstillinger/Stortinget/2015-2016/inns-2 01516-391/?lvl=0\#a1

${ }^{52}$ See https://www.aftenposten.no/norge/politikk/i/rE9w/listhaug-beskyldes-for-misbruk-av-rapport-omasylbarn?
} 
statuses. For example, in 2017, rejected unaccompanied Afghan minors accounted for 86 of the 713 total decisions, while 346 were granted temporary status with rejection at the age of 18 . Hence, in practice, the Norwegian authorities rejected $61 \%$ of unaccompanied Afghan minors in 2017 (UDI 2017). In Norway, as in Sweden, the strict approach towards Afghan minors was seen as highly controversial. ${ }^{53}$

Consequently, based on the parliament's resolution of November 14, 2017, a limited group of unaccompanied minors (mostly Afghans) with temporary status were given the right to have their cases re-examined. The requirements were, among others, that the minor had been referred to IFA/IRA and that the decision had been made after October 1, 2016. The changes came into force on February 1, 2018. However, the practical implementation of the decision turned out to be complicated.

According to the Police Immigration Unit, 90\% of Afghans who turned 18 in October had left the reception centres in $2017 .{ }^{54}$ Due to the above-mentioned regulations regarding deportations to Afghanistan, the forced returns were considered a real threat by Afghan minors entering adulthood. Most of them, therefore, fled to other European countries, where they hoped to obtain a better assessment of their asylum case or where it was easier to avoid deportations and live as irregular migrants (Valenta and Garvik 2019). This situation made it difficult to reach out to those youths who could apply for a new consideration of their asylum applications. When the application deadline expired, 399 unaccompanied minors had applied for a new assessment. Only 137 youths fulfilled the requirements for new case processing; among them, 106 were granted renewable temporary residence because of strong humanitarian considerations. $^{55}$

Unlike the Swedish High School Act, the Norwegian legislation required identity documentation to provide permanent residence status. Since 2018, few unaccompanied minors have obtained non-renewable temporary permissions in Norway. However, many still receive restricted renewable temporary residence, which must be renewed every year, as it is very difficult to obtain required identity documents from Afghanistan.

To summarise, we can identify a decline in non-renewable permits that granted temporary status with rejection at the age of 18 in Norway. This may be regarded as a gradual softening of the highly restrictive political response towards unaccompanied Afghan minors. Yet, the Norwegian authorities have increased the use of renewable temporary residence permits. It remains clear that the increase in renewable temporary residence permits based on strict ID-documentation requirements undermines Afghans' integration into Norwegian society. These temporary residence permits grant fewer rights than permanent residence permits, contributing to a limbo situation of "differential inclusion" for unaccompanied Afghan minors.

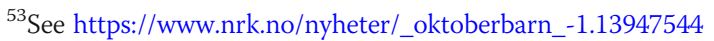

${ }^{54}$ See https://www.dagsavisen.no/innenriks/9-av-10-har-forsvunnet-1.1053313

${ }^{55}$ These youths have been granted a subsidiary permit that can be renewed every year until they have delivered a passport that confirms their identity information. This permit does not provide grounds for family reunification or permanent residence, see https://www.udi.no/aktuelt/atte-av-ti-oktoberbarn-fikkopphold/
} 


\section{Conclusion}

This article has explored the policy responses of Scandinavian countries to a large increase in the number of asylum seekers in 2015. We have distinguished between the overall responses to the crisis and policies towards unaccompanied Afghan minors in Sweden, Norway and Demark. The increase in the influx of asylum seekers in 2015 resulted in restrictive asylum policies, combined with an introduction of both external and internal border controls in the three Scandinavian countries.

In the wake of the crisis, we have traced some of the traditional tendencies in the responses of the three countries, where Sweden takes the least restrictive stance while Denmark appears as the most restrictive of the three countries. Denmark stands out with the most restrictive policy, as the authorities in the country only grant temporary residence permits to asylum seekers, regardless of the reason for the protection. The High School Act in Sweden and the conversions of non-renewable temporary residence permits in Norway may represent attempts at gradual softening of the restrictive policies. Yet, despite these differences, the general trend of restrictive asylum policies prevails in every Scandinavian country. Indeed, it is clear that since 2015, the Scandinavian policy approach to unaccompanied minors has been radically transformed. Before 2015, policies maintained a perspective that involved social protection, children's rights and integration. Since "the crisis", the policy responses and instruments have primarily been concerned with migration control and deterrence. This change in perspective from protection and integration towards closed borders, temporality, rejection and return policies clearly indicates a huge shift in the Scandinavian approach to displaced children. The traditional ideological underpinnings of the child's best interest principle have been overshadowed by migrant-regulatory considerations. This shift of perspective has been particularly evident in the case of Afghan youths. For instance, before the mass influx, unaccompanied Afghan minors were perceived as an especially vulnerable group of asylum seekers, and as a rule, they were granted permanent permits to stay in both Sweden and Norway. In contrast, most of the unaccompanied Afghan minors who arrived in Scandinavia in 2015 were granted temporary residence permits.

Because of difficulties regarding deportations, many non-citizens still live within the Scandinavian context. A large share of unaccompanied Afghan minors has also fled the Scandinavian authorities. Accordingly, it is reasonable to believe that the restrictive policies in Scandinavia have produced several non-citizens or illegal migrants in other European countries. ${ }^{56}$ The new migrant control framework has also constructed various categories of temporary, semi-legal citizens and non-citizens within Scandinavia. These young adults have been trapped in limbo for years.

These temporary and semi-legal residents face huge challenges regarding insecurity and how to plan for their future. Non-citizens have been placed in an even more vulnerable position. Their attempt to gain residency permits has been blocked by the authorities. Non-citizens are seen as outsiders and not a part of society. The semi-legal categories of refugees force these people to become second-class citizens who must

\footnotetext{
${ }^{56}$ For example, in 2017, 90\% of unaccompanied minors from Afghanistan who received temporary protection in Norway and rejection left the reception centres: https://www.dagbladet.no/nyheter/pa-ett-ar-har-467-barnromt-fra-norske-asylmottak-over-halvparten-har-forsvunnet-helt/68803818. Many of them left for France and other European countries, where they live as irregular migrants, See https://www.newsinenglish.no/2017/ 07/31/life-too-difficult-for-illegal-aliens/
} 
climb the ladder to a more secure position. Accordingly, this new type of citizenship may be subject to a unique set of punishments and rewards. As several researchers point out, semi-legal citizens may risk sliding downwards to illegality if they fail to meet the authorities' requirements (Goldring and Landolt 2013). In this way, the new migration control policies and the aim of deterrence have not only contributed to a hard outside but also to a hard inside approach (Bosniak 2007). Hence, the Scandinavian model and ideal of universal and equal citizenship have been transformed into systems based on stratification and differential inclusion of unaccompanied migrant children. This new Scandinavian approach to citizenship not only contributes to insecure positions of semi-legal and non-citizens, it may also have a long-lasting effect in reconceptualising what is meant by protection and universalism within Scandinavia.

\section{Authors' contributions}

The author(s) read and approved the final manuscript.

\section{Competing interests}

The authors declare that they have no competing interests.

\section{Author details}

${ }^{1}$ Norwegian University of Science and Technology (NTNU), Trondheim, Norway. ${ }^{2}$ Norwegian University of Science and Technology (NTNU)/NTNU Social Research, Trondheim, Norway.

Received: 24 June 2020 Accepted: 22 December 2020

Published online: 22 April 2021

\section{References}

Allsopp, J., \& Chase, E. (2019). Best interests, durable solutions and belonging: Policy discourses shaping the futures of unaccompanied migrant and refugee minors coming of age in Europe. Journal of Ethnic and Migration Studies, 45(2), 293-311. https://doi.org/10.1080/1369183X.2017.1404265.

Amnesty International (2018). European states should stop forcing people to danger in Afghanistan. Public Statement. Index: ASA 11/9262/2018, 8 October 2018. https://www.amnesty.org/download/Documents/ASA1192622018ENGLISH.pdf.

Bech, E. C., Borevi, K., \& Mouritsen, P. (2017). A 'civic turn' in Scandinavian family migration policies? Comparing Denmark, Norway and Sweden. Comparative Migration Studies, 5(1), 7. https://doi.org/10.1186/s40878-016-0046-7.

Betts, A., \& Collier, P. (2017). Refuge: Transforming a broken refugee system. Penguin UK.

Bosniak, L. (2007). Varieties of citizenship. Fordham Law Review, 75(5), 2449-2453. https://ir.lawnet.fordham.edu/flr/vol75/iss5/5.

Brekke, J. P., \& Brochmann, G. (2014). Stuck in transit: Secondary migration of asylum seekers in Europe, national differences, and the Dublin regulation. Journal of Refugee Studies, 28(2). https://doi.org/10.1093/jrs/feu028.

Brekke, J. P., Røed, M., \& Schøne, P. (2016). Reduction or deflection? The effect of asylum policy on interconnected asylum flows. Migration Studies, 5(1), 65-96. https://doi.org/10.1093/migration/mnw028.

Brekke, J. P., \& Staver, A. (2018). The renationalisation of migration policies in times of crisis: The case of Norway. Journal of Ethnic and Migration Studies, 44(13), 2163-2181. https://doi.org/10.1080/1369183X.2018.1433026.

Brochmann, G., \& Hagelund, A. (2012). Welfare state, nation and immigration. In Immigration policy and the Scandinavian welfare state 1945-2010, (pp. 1-24). London: Palgrave Macmillan.

Crawley, H., \& Skleparis, D. (2018). Refugees, migrants, neither, both: Categorical fetishism and the politics of bounding in Europe's 'migration crisis'. Journal of Ethnic and Migration Studies, 44(1), 48-64. https://doi.org/10.1080/1369183X.2017. 1348224.

De Graeve, K., Vervliet, M., \& Derluyn, I. (2017). Between immigration control and child protection: Unaccompanied minors in Belgium. Social Work and Society, 15(1). http://hdl.handle.net/1854/LU-8530221.

European Commission (2016). 10th European forum on the rights of the child - the protection of children in migration.

Eurostat (2016). Asylum applicants considered to be unaccompanied minors. Newsrelease 87/2016-2 May 2016. https://ec. europa.eu/eurostat/documents/2995521/7244677/3-02052016-AP-EN.pdf/19cfd8d1-330b-4080-8ff3-72ac7b7b67f6.

Eurostat (2018). Asylum quarterly report $1^{\text {st }}$ quarter 2018. Statistics Explained. http://ec.europa.eu/eurostat/statistics-explained/.

Gammeltoft-Hansen, T., \& Tan, N. F. (2017). The end of the deterrence paradigm? Future directions for global refugee policy. Journal on Migration and Human Security, 5(1), 28-56. https://doi.org/10.1177/2F233150241700500103.

Garvik, M. (2018). Mangfold og inkludering i arbeidslivet i Sverige, Danmark og Norge. En komparativ studie av reisende ideer og utviklingstrender i den skandinaviske velferdsmodellen. Doctoral Thesis NTNU, 2018:13.

Goldring, L., \& Landolt, P. (2013). The conditionality of legal status and rights: Conceptualizing precarious non-citizenship in Canada. In L. Goldring, \& P. Landolt (Eds.), Producing and negotiating non-citizenship: Precarious legal status in Canada (pp. 3-27). Toronto: University of Toronto Press.

Green-Pedersen, C., \& Krogstrup, J. (2008). Immigration as a political issue in Denmark and Sweden. European Journal of Political Research, 47, 610-634. https://doi.org/10.1111/j.1475-6765.2008.00777.x.

Hall / NRC / IDMC (2018). Challenges to IDPs' protection in Afghanistan. Commissioned by NRC / IDMC and funded by the European Union and the Norwegian Ministry of Foreign Affairs. https://static1.squarespace.com/static/5cfe2c8927234 e0001688343/t/5d1f21e5d7cf6b00012937b7/1562321391421/NRC-IDP_Afghanistan_FINAL.pdf.

Hedlund, D. (2016). Drawing the limits: Unaccompanied minors in Swedish asylum policy and procedure. Stockhoms universitet. Holmbergs: Malmö https://www.diva-portal.org/smash/get/diva2:906409/FULLTEXT01.pdf. 
Igesund, S. M. (2015). Midlertidig opphald for einslege mindreårige asylsøkjarar-eit akseptabelt verktøy for internasjonalt vern? Kritisk juss, 41(01), 14-36. https://www.idunn.no/kritisk_juss/2015/01/midlertidig_opphald_for_einslege_ mindreaarige_asylsoekjarar_.

Isaksen, J. V. (2020). The framing of immigration and integration in Sweden and Norway: A comparative study of official government reports. Nordic Journal of Migration Research, 10(1), 106-124. https://doi.org/10.2478/njmr-2019-0033.

Könönen, J. (2018). Differential inclusion of non-citizens in a universalistic welfare state. Citizenship Studies, 22(1), 53-69. https://doi.org/10.1080/13621025.2017.1380602.

Krzyżanowski, M. (2018). "We are a small country that has done enormously lot": The 'refugee crisis' and the hybrid discourse of politicizing immigration in Sweden. Journal of Immigrant \& Refugee Studies, 16(1-2), 97-117. https://doi.org/10.1080/ 15562948.2017 .1317895$.

Krzyżanowski, M., Triandafyllidou, A., \& Wodak, R. (2018). The mediatization and the politicization of the "refugee crisis" in Europe. Journal of Immigrant and Refugee Studies, 16(1-2), 1-14. https://doi.org/10.1080/15562948.2017.1353189.

Lag (2016). Om tillfälliga begränsningar av möjligheten att få uppehållstillstånd i Sverige. https://www.riksdagen.se/sv/ dokument-lagar/dokument/svensk-forfattningssamling/lag-2016752-om-tillfalliga-begransningar-av_sfs-2016-752.

Lag (2017). Om uppehållstillstånd för studerande på gymnasial nivå. https://www.riksdagen.se/sv/dokument-lagar/dokument/ svensk-forfattningssamling/lag-2017353-om-uppehallstillstand-for_sfs-2017-353.

Lemberg-Pedersen, M. (2015). The rise and fall of the ERPUM pilot: Tracing the European policy drive to deport unaccompanied minors. (Working Paper 108). Oxford: The Refugees Studies Centre.

Lemberg-Pedersen, M. (2018). The "imaginary world" of nationalistic ethics: Feasibility constraints on Nordic deportation corridors targeting unaccompanied afghan minors. Etikk i praksis-Nordic Journal of Applied Ethics, 12(2), 47-68. https://doi. org/10.5324/eip.v12i2.2425.

Lemberg-Pedersen, M. (2019). Manufacturing displacement. Externalization and postcoloniality in European migration control. Global Affairs, 1-25. https://doi.org/10.1080/23340460.2019.1683463.

Lidén, H., Stang, E. G., \& Eide, K. (2017). The gap between legal protection, good intentions and political restrictions Unaccompanied minors in Norway. https://hdl.handle.net/10642/5450.

Lietaert, I., Behrendt, M., Uzureau, O., Adeyinka, S., Rota, M., Verhaeghe, F., \& Derluyn, I. (2019). The development of an analytical framework to compare reception structures for unaccompanied refugee minors in Europe. European Journal of Social Work, 1-17. https://doi.org/10.1080/13691457.2019.1682974.

Majidi, N. (2017). From forced migration to forced returns in Afghanistan: Policy and program implications. TransAtlantic Council on Migration. Migration Policy Institute.

Migrationsverket (2014). Beviljade uppehållstillstånd och registrerade uppehållsrätter, första och andra instans. https://www. migrationsverket.se/download/18.39a9cd9514a346077211b08/1485556219063/Beviljade\%20uppehållstillstånd\%20och\%2 Oregistrerade\%20uppehållsrätter\%202014.pdf.

Migrationsverket (2017). Beviljade uppehållstillstånd och registrerade uppehållsrätter, första och andra instans. https://www. migrationsverket.se/download/18.4100dc0b159d67dc6146d5/1515053488342/Beviljade\%20uppehållstillstånd\%202017.pdf.

Migrationsverket (2018). Beviljade uppehållstillstånd och registrerade uppehål/srätter, första och andra instans. https://www. migrationsverket.se/download/18.4cb46070161462db113174/1550131463060/Beviljade_uppehållstillstånd_2018.pdf.

Neumayer, E. (2004). Asylum destination choice: What makes some west European countries more attractive than others? European Union Politics, 5(2), 155-180. https://doi.org/10.1177/2F1465116504042444.

O'Brien, P. (2019). Bordering in Europe: Differential inclusion. Border Crossing, 9(1), 43-62. https://doi.org/10.33182/bc.v9i1.819.

Owen, D. (2019). Refugees, EU citizenship and the common European asylum system: A normative dilemma for EU integration. Ethical Theory and Moral Practice, 22(2), 347-369. https://doi.org/10.1007/s10677-019-09973-x.

Parusel, B. (2017). Unaccompanied minors in the European Union-definitions, trends and policy overview. Social Work \& Society, 15(1). https://socwork.net/sws/article/view/501.

Sandermann, P., \& Zeller, M. (2017). Young people called "unaccompanied minors" and European welfare states: A brief introduction to this special issue. Social Work \& Society, 15(1). https://www.socwork.net/sws/article/view/493.

Save the Children (2018). From Europe to Afghanistan: Experiences of child returnees. https://reliefweb.int/sites/reliefweb.int/ files/resources/SC-From_Europe_to_Afghanistan-screen\%201610.pdf. Accessed 2 Dec 2019.

Scholten, P., \& van Nispen, F. (2015). Policy analysis and the "migration crisis": Introduction. Journal of Comparative Policy Analysis, 17(1), 1-9. https://doi.org/10.1080/13876988.2015.1006408.

Sigona, N. (2018). The contested politics of naming in Europe's "refugee crisis". Ethnic and Racial Studies, 41(3), 456-460. https://doi.org/10.1080/01419870.2018.1388423.

Squire, V., Strange, M., \& Lundberg, A. (2017). Irregular migration struggles and active subjects of trans-border politics: New research strategies for interrogating the agency of the marginalised. Politics, 3, 37. https://doi.org/10.1177/0263395717715856.

Triandafyllidou, A. (2018). A "refugee crisis" unfolding: "Real" events and their interpretation in media and political debates. Journal of Immigrant \& Refugee Studies, 16(1-2), 198-216. https://doi.org/10.1080/15562948.2017.1309089.

Triandafyllidou, A., \& Dimitriadi, A. (2014). Deterrence and protection in the EU's migration policy. The International Spectator, 49(4), 146-162. https://doi.org/10.1080/03932729.2014.956280.

UDI (2017). Asylvedtak etter statsborgerskap og utfall for enslige mindreårige asylsøkere. https://www.udi.no/statistikk-og-analyse/ statistikk/asylvedtak-etter-statsborgerskap-og-utfall-for-enslige-mindrearige-asylsokere-2017/.

UDI (2018). Asylvedtak etter statsborgerskap og utfall for enslige mindreårige asylsøkere. https://www.udi.no/statistikk-og-analyse/.

UDI (2019). Asylsøknader enslige mindreårige asylsøkere. https://www.udi.no/statistikk-og-analyse/.

Udlæningestyrelsen (2017). Tal og Fakta på udlæningeområdet 2017. https://www.nyidanmark.dk/da/Numbers/tal_fakta.

Udlæningestyrelsen (2018). Tal og Fakta på udlæningeområdet2018. https://www.nyidanmark.dk/da/Numbers/tal_fakta.

UNHCR (2018). Eligibility guidelines for assessing the international protection needs of asylum seekers from Afghanistan. United Nations High Commissioner for Refugees (UNHCR) 30 August 2018 HCR/EG/AFG/18/02. https://www.refworld.org/ docid/5b8900109.html.

Valenta, M., \& Bunar, N. (2010). State assisted integration: Refugee integration policies in Scandinavian welfare states: The Swedish and Norwegian experience. Journal of Refugee Studies, 23(4), 463-483. https://doi.org/10.1093/jrs/feq028.

Valenta, M., \& Garvik, M. (2019). Enslige mindreårige asylsøkere - Opplevelser og mestring av midlertidighet. Tidsskrift_for_ velferdsforskning, 22(2), 126-145. 
Valenta, M., \& Jakobsen, J. (2020). Conceptualising Syrian war migrations: Displacements, migrants' rights and the major reception regimes. International Journal on Minority and Group Rights. https://doi.org/10.1163/15718115-02704006.

Valenta, M., Lønning, M. N., Jakobsen, J., \& Župarić-lljić, D. (2019). European asylum policies and the stranded asylum seekers in southeastern Europe. Journal of Refugee Studies, 32(Special_Issue_1), 162-171. https://doi.org/10.1093/jrs/fey063.

Valenta, M., \& Thorshaug, K. (2013). Restrictions on right to work for asylum seekers: The case of the Scandinavian countries, Great Britain and the Netherlands. International Journal on Minority and Group Rights, 20(3), 459-482. https://doi.org/10. $1163 / 15718115-02003006$

Vitus, K., \& Lidén, H. (2010). The status of the asylum-seeking child in Norway and Denmark: Comparing discourses, politics and practices. Journal of Refugee Studies, 23(1), 62-81. https://doi.org/10.1093/jrs/feg003.

Wernesjö, U. (2019). Across the threshold: Negotiations of deservingness among unaccompanied young refugees in Sweden. Journal of Ethnic and Migration Studies, 1-16. https://doi.org/10.1080/1369183X.2019.1584701.

\section{Publisher's Note}

Springer Nature remains neutral with regard to jurisdictional claims in published maps and institutional affiliations.

Submit your manuscript to a SpringerOpen ${ }^{\odot}$ journal and benefit from:

- Convenient online submission

- Rigorous peer review

- Open access: articles freely available online

- High visibility within the field

- Retaining the copyright to your article

Submit your next manuscript at $\boldsymbol{\nabla}$ springeropen.com 